\title{
Human Connections in Red Badge of Courage
}

\author{
Syed Afroz Ashrafi \\ Prince Sattam Bin Abdulaziz University, Alkhirj, Saudi Arabia \\ E-mail: ashrafiafroz@gmail.com
}

Received: 19-12-2015

Published: 01-05-2016
Accepted: 24-02-2016

doi:10.7575/aiac.ijalel.v.5n.3p.199
Advance Access Published: March 2016

URL: http://dx.doi.org/10.7575/aiac.ijalel.v.5n.3p.199

\begin{abstract}
The paper Human connection in Red badge of Courage sought to reestablish the notion that humanity survives the ravages of war, the war that kills and alienates a good chunk of human populace. The sounds of bullets cannot soften the tissues of heart, rather it only appalls humanity. Crane's human connection is stressed as the succor for the tormented and oppressed nations mainly through wars.
\end{abstract}

Keywords: war, nations, death, savagery

\section{Introduction}

In the history of any literature there are writers who either are unduly eulogized or extra ordinarily underplayed by the critics and commentators who are generally guided by their motivational impulses that at times are irrational. American fiction is a narrative of war or its compulsive obsessions with adventure or the possibilities of human actions either thrilled it most or in retrospect reflected the paucity of social texture. Moby Dick raised the spectacle of injured human pride which involved a sense of war with the forces that subdued the currents of human strength, a thread picked up more ingeniously later on by Earnest Hemmingway and he rehashed the stories of human splendor with spices of scintillating y prose. It's not very clear, who bludgeoned the spirit of dullness by oppressing the dormant instincts of action? War as a theme, the realistic wars in America, the diced up ruins at the altar of wickedly ambitious political powers heaping fire on earth to regale the instincts of the dull pulsing of blood possibly raised the image of devastation as a serious manifestation of sadism?

There are questions in the context of war as a healer or as a solution to issues that dialogue cannot resolve. Perhaps America is both a victim and an aggressor not today rather it has been so given its turbulent and chaotic history. Peace is sometimes restored by war or war sometimes shatters the peace in pursuit of territorial authority. Whether Stephen Crane wrote Red Badge of Courage with intent to probe the psychology of warfare through Henry Fleming or he delved into the disturbed psyche of an individual for whom the war was the occasion to rise into the hall of fame? These are questions raised by a writer not much read in America or even not read much by the intellectuals of the land to find any merit in his psycho analysis of a character until British critics intruded into the imagination of a writer basically known as one of the many in the fray. Red Badge of Courage perhaps is as important as the likes of Moby Dick, Grapes of Wrath, The Old Man and the Sea or Manhattan Transfer since it looks deep into the mechanism of a confused mind that wanted to be sung as a hero in his own life time. Whether Crane was a writer of substance or not is not my concern to examine but my objective would be focused around deconstructing the inherent gaps in the text in terms of ideological undercurrents Crane left for the reading world. It will be both interesting and challenging to unearth the spectacle of reading through the mind of a character who happened to be ignored or read rather casually when he was created by supposedly one of the lesser American minds. War novels have its own tradition as a host of American writers ranging from Dos Passos to Hemingway were directly involved in the Ambulance Corps Services knew the perils, horrors and the trails of terrors war imposed on a spate of generations and they continued to reel under its debris for a long period of time. Dos Passos went to the extent of saying with reference to the World War II that' Horror is so piled upon horror that there can be no more" a statement conceived in frustration and delivered in pragmatics of war heritage. Dos Passos in Three Soldiers and One man's Initiation: 1919 cracks down at the repressive political forces that left behind a generation of crippled, horrified and traumatized malevolent portraits of youth in a land ravaged by the horrendous nature of war. Violence can be glorified by those who command political authority and be turned into a thrilling encounter to combat the ones escaping the gallows of subjugation. Whites did most of the damage to the human race which Joseph Conrad calls political hypocrisy of the West that conquered the geography in the name of civilizing mission and he is inclined to see it as a ruse to rule rather than to bring the wild into the civilizational fold. Chinua Achebe though was unhappy over his description of the African forest as the happy hunting ground of the rampaging West although Conrad had meant a different context altogether. The point therefore is the humane angle represented through the prism of civil war that distorts the idea of freedom to live under the choice of being. Stephen Crane's sensitive, profound and realistic portraiture of a man serving under the illusion of heroism discloses the ugly face of war that can never be the succour to humanity, a point driven home by Crane in the midst of political chaos and the rising ambitions of the politically hungry nations to slip into the sleeping freedom of the weak guardians of their boundaries. 
Crane cries against the gross miscarriage of justice to the nations without the resources to defend its territory when the pounding is done by the dreaded phantoms of political imposters. Red Badge of Courage is just a symbol of wound apparently but under its surface it represents the mindless scars that pierce through a bruised psychology of destructions. It was not a great novel, at least not supposed to be one when written but critics by going into the philosophy espoused by Crane could discover the appalling and intimidating bruises the wounds of war left on the sands of time. One of the aspects that can be stretched to a certain degree of acceptability is the approach of the writer in the context of the bleeding humanity in general and the stupefied response of a soldier who misconstrued the very concept of war as a force to redeem the injured self. Launching himself into the glorified career as a soldier Henry Fleming strode to the shore of wounds carrying him through the trials of human spirit in the hour of dipping disgrace. He was neither salvaged nor did the social rectitude ever dawn on him while taking the battlefield. At times dastardly he found himself to be, at times a committed soldier not frightened at the sight of the blood dripping from an injured body but at the end of it all he was lost in the dingy glare of a misplaced glory. Stephen Crane was more inclined to find a searching and scorching ambition of a soldier wedded to the dream of glory through the possibilities of action that would lift him beyond the commonplace status of a common soldier.

\section{Main Body}

Red Badge of Courage can thus be reconsidered for an interpretation that would reinforce the blurred and murky remembrance of the portraits hung on the walls of time to be revisited by casual readers only though the responses of George Wyndham, William Dean Howells and Hamlin Garland doing the damage control exercise to determine whether the novel would receive the critical attention as it was conceived by a mind the Americans knew little about except his audacious journalistic pursuits and the poetry, Black Riders? My objective here is to penetrate into the smitten consciousness of a soldier done in through the glory of the war and its implications in terms of a narrative of despair stemming from hypothetical constructions of the self. It would be quite pertinent to trace some of the novels written on war and then determine whether Red Badge of Courage is any different from them as far as the effects, scars and bruises are concerned and the response of a fighting soldier who is not battle weary still he has his own share of regrets for going too far out.

The war novels such as Regeneration by Pat Barker, Billynn's Long Half Time Walk by Ben Fountain, The Ghost Road by Pat Barker, Catch 22 by Joseph Heller, Farewell to Arms by Earnest Hemingway, All Quiet on the Western Front by Erich Maria Remarg and Birds Song by Sebastian Faulks generally talk about the vices of war as a political necessity and its subsequent concerns with the rise of political powers. These novels are more about the physical horrors and psychological alienation of the soldiers who suffer for no fault of theirs and if they fire bullets they don't even know the enemies as they are commanded by the General and the aftermath of the fired bullet is not their fault. These novels are narratives howsoever profound discuss the movements of the troops, the strategic positions soldiers are supposed to take and the soldiers are the very heroes whether they win or lose. Red is the colour that they spill and macabre is the language they speak. These novels are good at raising the devil of destructions, a horrified details of the dying soldiers, the civilian massacre and the cries, shouts, wails, chest thumping and the sobs all come within the ambit of what a soldier is to do even he faces death. The combat and death move side by side. They portray graphic horrors are engaged in mindless guzzling of the boundaries to strike a deal, a political deal to serve their masters. But does anyone realize what a soldier is through, what it makes to be a soldier? Dos Passos's two heroes Martin Howe and Franshaw are the victims of the arrogance imposed by the war upon them. They realize the futility of firing bullets, the absurdity of walking onto the battlefield when they question their own actions and its logicality. They are frustrated soldiers, angry individuals, malevolent representations of the failed political system and their agonies are theirs symbolizing the utter chaos within the self. Dos Passos too questions time and again in Three Soldiers the motifs of war that cripples the economy, shatters the land and leaves a mesmerizing impact on the psyche of the time. Radicalism he questions and castigates America's lust for power and position only to end up as a blood thirsty nation. But all these are the facts of the circumstances that generate war, the intrusion into the privacy of a nation and the plundering of the resources to build one's own empire. Hemingway in The farewell to Arms sounds like a soldier desperate and fatigued to make peace as war only extends the legacy of destructions. But Stephen Crane does no mourning, does not come hard on the wars but he basically disagrees with the envisaged vision of war through the portrayal of a General Henry Fleming whose discourse is the very discourse on the nature of the human intent in the context of realizing what it means to go into a war and what it means to be a soldier who kills, murders, indulges in mayhem and all these are not his personal causes, but the causes created by the ones ambitious enough to strike the sun down. Red Badge of Courage was the badge of shame early on for the Americans as they went up in flames accusing Stephen Crane of dehumanizing and denigrating the image of America as a savage nation and the Britons they suspected would be too delighted with this. Crane was accused of being anti national, and it's a fact that English critics were more liberal towards it as they could find its genesis in the works of Zola, Tolstoy, Kipling and the Russian realist painter Verestschagin.

Writes English Critic Sidney Brooks:

Crane's depiction of combat in Red Badge, assumed that Crane had fought in the Civil War. If Red Badge were altogether a work of the imagination, unbased on personal experience,' it's realism would be nothing short of a miracle. Crane's imaginative effort remains a marvel. 
Crane was the first novelist to grasp the significance of narrating the novel from the point of view of Private Henry Fleming. General's accounts had usually been written from the "band-box" viewpoint and emphasized large scale concerns (troop movements, tactical maneuvers', wins and losses), neglecting the much more limited but in many ways more intense experience of the anonymous foot soldier.

Both the critics Sidney Brooks and George Wyndham are in agreement with the nature of worked produced and under conditions that might have gone unnoticed given the early lukewarm response of the American readers and critics. But Red Badge of Courage is a serious manifestation of the life of a soldier who gradually discovers the beast of war and the disintegration of his own self both as a man and a soldier. His drafting into army was against the will of her mother, the zeal to usher in an action of his life, the judgements of a soldier who gets the feel of being into army, its monotony, its heartless world, the ridicule involved and the suspended actions Initially excited him.His universe rests on a more imagined glamour of war as the action of heroes, as the envisaged mission of battles fought to defend nothing, nothing in terms of the finality of objectives. Henry Fleming from an over enthusiast, rumbustious soldier gradually dissolves into a world where his fancies crash, where his dreams build and disappear and his human touch replaced by a more mechanized response to the human crisis. Henry Fleming's mother initial displeasure ignored otherwise by him given his high fervor and fanaticism, assurance and optimism are born to chase the utopia of being a soldier who was going to be the hero of his own life as per his visualizations though the wild ones. Henry Fleming had joined army for the catharsis of his own soul, for the liberation of the humbled and battered personality as there was nothing in his life that could be his elixir and hence army was his to be the amphitheater of all actions.

But his mother had discouraged him. She h looked with some contempt upon the quality of his war ardour and patriotism. She could calmly seat herself and with no apparent difficulty give him many hundreds of reasons why he was of vastly more importance on the farm than on the field of battle. She had had certain ways of expression that told him that her statements on the subject came from a deep conviction. Moreover, on her side, was his belief that her ethical motive in the argument was impregnable."

From early on Henry Fleming's mother was not inclined to accept his military ambitions and to the extent that even her farm held more importance than his army adventures. But Fleming was more resolute to go into it rather than to be swayed back into the seemingly insignificant muttering of his mother who he thought is more protective about her love than her dislike for the army service. It was not the best of patriotism nor the idea to serve the nation than to find a recourse to the gallery of hopes of lifting his spirits both as an individual and an army man who thus far only knew the actions and the thrill of war that would take him beyond the realms of obscurity. His universe zoomed around the idea of serving himself to escape the monotony of a life he thought is ideally suited for something he has a liking but again his mother would not spare her tantrums to his proposed actions.

One night, as he lay in bed, the winds had carried to him the clangoring of the church bell as some enthusiast jerked the rope frantically to tell the twisted news of a great battle. This voice of the people rejoicing in the night had made him shiver in a prolonged ecstasy of excitement. Later, he had gone down to his mother's room and had spoken thus: "Ma, I'm going to enlist."

His early excitement found expressions in telling her mother "Ma, I'm going to enlist." That would be his final deal even mother disagrees completely watching him go as if this was the last encounter she would ever have with her son. He left and his mother watched him go as if her heart was deserting her.

After complicated journeying with many pauses, there had come months of monotonous life in a camp. He had had the belief that real war was a series of death struggles with small time in between for sleep and meals; but since his regiment had come to the field the army had done little but sit still and try to keep warm.

Henry Fleming's high thoughts, his yearnings for an action ridden thrill keep him on his toes, what he had thought war to be but there was nothing he found in terms of his initial response to a well thought high pitched, bullet producing chaos and remained a still soldier, a soldier who had great hopes of unleashing his guns on the supposed armies. Nothing inspired him early on, nothing spurred him on early on, nothing stimulated him to sustain his exuberance to carry the weight of bullets on his back and wait for the commander's order of shoot. ,

Good Gawd," the youth grumbled, "we're always being chased around like rats! It makes me sick. Nobody seems to know where we go or why we go. We just get fired around from pillar to post and get licked here and get licked there, and nobody knows what it's done for. It makes a man feel like a damn' kitten in a bag. Now, I'd like to know what the eternal thunders we was marched into these woods for anyhow, unless it was to give the rebs a regular pot shot at us. We came in here and got our legs all tangled up in these cussed briers, and then we begin to fight and the rebs had an easy time of it. Don't tell me it's just luck! I know better. It's this derned old--"

The friend seemed jaded, but he interrupted his comrade with a voice of calm confidence. "It'll turn out all right in th' end," he said.

\section{Conclusion}

The expressions here are jarring that do not sustain the spirit of a soldier committed to losing his life to honour the land, to stay connected to the history of land even after his death and the churning out positions visualized albeit that 
posterity will embrace him. The supine, dull and the resigned, stupefied response of his colleagues who refuse to share his exuberance for they knew war is a dreary business and its nature does nothing to stimulate the soldiers sleeping on the rifle butts exploring the inactions of the past and the future. They are a bunch of people who are without emotions, without the normal breath, a human being generally has and here Stephen Crane drives the point home that a soldier is as much a human as any other human being could be, his destruction is the destruction of a thinking sane mind, his annihilation as a human being only turns him into a trigger happy robot who fires and holds the gun only in obedience to the superior without being into it.

The greater part of the men, discouraged, their spirits worn by the turmoil, acted as if stunned. They accepted the pelting of the bullets with bowed and weary heads. It was of no purpose to strive against walls. It was of no use to batter themselves against granite. And from this consciousness that they had attempted to conquer an unconquerable thing there seemed to arise a feeling that they had been betrayed. They glowered with bent brows, but dangerously, upon some of the officers, more particularly upon the red-bearded one with the voice of triple brass.

The passage again reveals the anatomy of frustration as they are not sure of the goals and the bullets direction either and this is what Stephan Crane looks at, a more humanistic angle, a more persuasive and rational investigation into the troubled war psyche of the befuddled soldiers. Red Badge of Courage is a novel not about what war does; it's about what the war does to the soldiers and how they are turned into heartless, phlegmatic, stoical figures unmoved even by the deaths of those they killed without being sure of the purpose. The humanistic angle overpowers Crane as he analyses the remains of the human elements into the traumatized lot of the soldiers. Henry Fleming's ambition goes turtle, the monotonous, splendid and mechanical responses of the Lieutenants and Generals leave him disillusioned as his heroism even though it was a perceived one finds no resolution. He is all aghast as a human who thinks, acts, nurses, nudges and goads himself to the final acceptance of himself as dry as dust hunter or a bundle of bones pieced together to help him stand on his own. Stephen Crane questions the motif of war, its impact on a generation of soldiers and the ones after, the audacity of war, the banality of its motifs, the absurdity of crimes committed against humanity. War is no succour, just a nightmare for the besieged humanity.

Red Badge of Courage attacks the monoliths of war, neurotic geographical conflicts, and politics of territorial expansion and the dehumanization of the soldiers who are puppetries in the hands of the powers controlling them. Henry Fleming is a coruscating portrait in destitution, in the war cries and the raised platforms of heroism which finally crumble once he is exposed to the reality of war conditions. His idealism takes a nosedive; his rational temper is tempered with notions imposed by his fellow soldiers devoid of human substance, devoid of comradery, devoid of a heart that listens to the music of emotions. They all end up as the dehumanized models by the imperial monsters. The novel Red Badge of Courage is a documentation of a human being thrilled early on, dissipates into an abandoned individual, into a fallen angel fighting frontiers and each fight turns him into a dull proclamation of the self, the lost tattered self where emotions turn into the comedy of the weak, into the surrender of the human foundations and into the submission to the calls of savagery given by the brutal face of imperial politics that revels in glory while celebrating doom. The American on the first appearance of the novel were sore, doubted Crane's nationalism, thought it to be British sponsored but with time it came to be recognized as the sensitive voice of a sensitive thinker who did not share anything with The Diary of a Young girl or Tin Drum or Everything is quiet on the Western Front. It's not anti-Nazi, it's not anti-Jew or Christian or any other religion or nation. It pleads debates and argues about the importance of a soldier's life who is not to be discarded in favor of savagery, in favor of horrors, in favor of the misdeeds committed by the power hungry nations. Henry Fleming is a moving portrait in the vices of war, a touching narrative of disintegration and a profound representation of what war brings to the mankind. It's the sound of the bullet that appalls Stephen Crane, and it's the cries of the soldiers that assail tender tissues of his heart to the extent that it finds reflections in Red Badge of Courage which goes down as the badge of the shame. The title itself looks as if he adores the torrential raining down of bullets, the heart wrenching blaring of tanks and the balls of fire that erupt to engulf the very premises of the human existence. It's a novel that restores the dignity of the dead and castigates the arrogance of the gun totting politically ambitious nations wreaking havoc upon the earth.

\section{References}

Atlantic Monthly, M. (1896). Review of The Red Badge of Courage. Crane, S. (2006). The Red Badge of Courage. Prestwick House Literary Touchstone Class. Penguin.

---. (1988). Amy Kaplan's The Social Construction of American Realism.

---. (1926). Joseph Conrad remembered in Last Essays.

--- . (1992). Giorgio Mariani's Spectacular Narratives: Representations of Class and War in the American 1890s. 